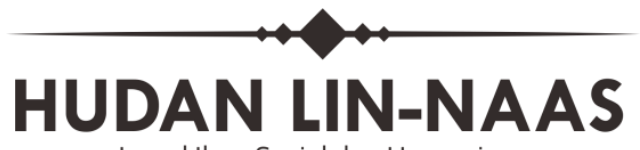

Jurnal Ilmu Sosial dan Humaniora

Volume: 2, no 2, Juli-Desember 2021

ISSN: 2775-1198(p), (2775-2755(e)

http://ejournal.idia.ac.id/index.php/hudanlinnaas/index

\title{
PERAN DAKWAH LEMBAGA EL-PSIKA ALAMIEN PRENDUAN TERHADAPPERUBAHAN KEPRIBADIAN MASYARAKAT
}

\author{
Suhendi \\ Institut Dirosat Islamiyah Al-Amien Prenduan \\ Hendydolala14@gmail.com
}

\begin{abstract}
Abstrak:
Dakwah sebagai proses perubahan sosial, ia berperan dalam upaya perubahan nilai dalam masyarakat, sesuai dengan tujuan-tujuan dakwah Islam. Mengingat pentingnya kehidupan yang Islami, tarbawi dan ma'hadi dikalangan masyarakat Pragaan laok, terutama dalam merubah kepribadian masyarakat Pragaan Laok, maka lembaga EL-PsikA memiliki peran yang penting dalam merubah kepribadian masyarakat Pragaan Laok khususnya, bagi para masyarakat yang memiliki watak kepribadian yang keras melalui proses dakwah yang diberikan oleh lembaga tersebut. Berdasarkan uraian tersebut, peneliti menemukan keunikan yang menjadi titik permasalahan yang cukup menarik untuk diteliti. Salah satu keunikan itu adalah meskipun sebagian dari mereka tergolong masyarakat yang memiliki watak sangat keras temyata mereka dapat merubah kepribadiannya melalui terapan dakwah dari eL-PsikA.Peneliti menggunakan pendekatan kualitatif lapangan. Metode penelitian yang digunakan adalah wawancara, observasi, dan dokumentasi. Adapun keabsahan data peneliti menggunakan triangulasi dengan dua jalan yaitu: membandingkan data hasil pengamatan dengan hasil wawancara dengan triangulasi antar metode yaitu membandingkan keadaan dan perspektif seseorang dengan berbagai pendapat dan pandangan orang lain. Hasil penelitian bahwa peran dakwah lembaga ElPsikA terhadap dakwah di masyarakat Pragaan laok dengan beberapa metode pendekatan yaitu pedekatan penawaran, pendekatan dengan cara hikmah, pedekatan bil mau'idah hasanah. Sedangkan pendekatan dakwah lembaga ElPsikA Al-Amien Prenduan untuk memperbaiki kepribadian masyarakat dengan cara mengajak masyarakat untuk melakukan pendekatan kepada Allah yang
\end{abstract}


bersifat ruhaniah dengan bimbingan dzikir bathiniah atau dalam istilah lain adalah dzikir dua dimensi yang meliputi bacaan shalawat dan istighfar sehingga dapat menjaganya siang dan malam. Dengan adanya bimbingan dzikir tersebut membantu untuk meningkatkan spritualitas yang berkaitang dengan keimanan kepada Allah SWT.

Kata Kunci : Dakwah, Lembaga el-Psika, Kepribadian

\begin{abstract}
:
Da'wa is a process of social change, it roles in changing social value attempts, Appropriate with the goals of Islamic Da'wa. In this case, reminding the important of Islami, Tarbawi and Ma'hadi life on a circle of people in Pragaan laok, so that way, El-PsikA has an important role to change the public personality especially for the people who has stern personality through the process of Da'wa given by the foundation. According to the description above, the researcher found a unique which was becoming a problem that interested to research. One of the unique is, although most of them have a stern personality, they could change their personality by the Da'wa from the El-PsikA foundation. For the more to discover about the role of Da'wa El-PsikA foundation, the researcher used qualitative field rapprochement. This rapprochement is using interview, observation and documentary method. This method will be processed by the researcher to get data and information. The subject of this research are from the organizers of El-PsikA Foundation and the Pragaan Laok society. For the validity of data, the researcher used triangulation with two ways; compare the result of observation with the result of interview with the triangulation each method that is comparing the situation and a perspective with the opinions and other perspective.In finding data, the researcher found that the Da'wa of El-PsikA foundation has role for Pragaan laok Society with some rapprochement methods, they are;offering rapprochement, rapprochement with Hikmah,andrapprochement with Mau'idah al-Hasanah. Meanwhile, the rapprochement of Da'wa in El-PsikA foundation Al-Amien Prenduan for fixing the social personality is inviting people approach to Allah swt spiritually with the guidance of DzikrBhatiniahor in other word called as Dizkrin two dimensions that included reciting Shalawatand Istighfarso that both can guard people all day long. By this Dizkrguidance, people will increase their spirituality which has connection with the faith for Allah swt.
\end{abstract}

Keywords: Da'wa,el-Psika,Personality.

\title{
PENDAHULUAN
}

Dewasa ini, ketika gejala kehidupan semakin kompleks karena terjadinya berbagai diferensiasi dalam bidang kehidupan, maka keinginan untuk menghadirkan ajaran agama Islam yang lebih kontributif dan kontekstual menjadi kebutuhan yang tidak 
bisa ditunda-tunda lagi. Karena sebagaimana diketahui ajaran suatu agama yang terekam melalui ayat-ayat suci Al-Qur'an dan al-Hadits, ajaran-ajaran tersebut tidak akan mempunyai makna ketika tidak mampu di break down menjadi penduan oprasional fungsional yang dapat dirasakan bagi kebutuhan ummat manusia.

Manusia adalah makhluk yang selalu berkeinginan untuk selalu hidup berdampingan dengan orang lain. Oleh karena itu, manusia juga disebut sosial animal yang mempunyai naluri untuk senantiasa hidup bersama dalam kerukunan dan keyakinan. Manusia memang makhluk yang serba unik, dengan keunikan yang misterius, Jelaluddin Rahmat mengungkapkan. Bahwa manusia dibutuhkan penjelasan dan interpretasi yang lebih banyak dibandingkan dengan yang dibutuhkanselain manusia. Tidak ada makhluk di dunia ini yang lebih membutuhkan penjelasan dan interpretasi selain manusia. ${ }^{1}$

Dalam hal ini, sudah seharusnya bagi manusia untuk saling bergaul karena eksistensi dirinya sebagai makhluk yang tidak sempurna bukan berarti bebas dari masalah-masalah kehidupan. Dalam pergaulan antara sesama manusia sering muncul konflik yang menyebabkan ketidak harmonisan interaksi tersebut. Bahkan, konflik itu dapat menyebabkan kegoncangan dan keprihatinan masyarakat secara terus menerus.

Islam dengan ajaran dasarnya aqidah, syari'ah dan akhlak merupakan pedoman bagi manusia dalam rangka pergaulan dengan sesamanya. Islam dapat menjadi pilar dalam menciptakaan keharmonisan, kedamaian dan ketentraman hidup bermasyarakat.Meskipun demikian sebagai agama yang sempurna, Islam tentunya menghenaki jika seluruh umatnya berada dalam kebenaran tanpa ada perselisihan yang mengakibatkan ketidak harmonisan dalam setiap kehidupannya. ${ }^{2}$

Problematika sosial saat ini yaitu perkembangan zaman yang diikuti dengan ilmu pengetahuan dan teknologi semakin hari semakin pesat, dan semakin kompleks akan tetapi dibalik itu ternyata melahirkan manusia-manusia yang jauh dari nilai-nilai

\footnotetext{
1 Jalaluddin Rahmat, Psokologi Agama (Jakarta: PT Raja Grafindo Persada, 2012), 155.

${ }^{2}$ Wahyu llahi, Komunikasi Dakwah, (Bandung: PT Remaja Rosdakarya, 2013), 24.
} 
keagamaan, sehingga mengakibatkan problematikan permasalahan yang muncul karena ketidak sanggupannya untuk menyesuaikan diri dari perkembangan zaman.

Maka untuk menjawab tantangan zaman yang semakin memperparah kehidupan dengan berbagai problematika permasalahan baik dari dorongan dalam diri maupun dorongan dari luar, agama Islam menghadirkan konsep kewajiban berdakwah bagi setiap umatnya, tujuannya adalah untuk membenahi persoalan-persoalan, ataupun konflik-konflik kehidupan yang di sebabkan oleh egonya sendiri sehingga dengan adanya dakwah tersebut dapat mengembalikan eksistensinya menuju jalan kebenaran sesuai dengan petunjuk Al-Qur'an dan As-Sunnah.

Sebagaimanafirman Allah di dalam Al-Qur'an Surah An-Nahlayat: 125: ${ }^{3}$

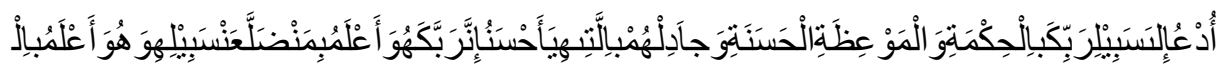
مُهُهنتَِينَ (سورة النحل :125)

Artinya: "Serulah manusia kepada jalan Tuhan-mu dengan hikmah dan pelajaran yang baik dan bantahlah mereka dengan cara yang yang baik, sesungguhnya Tuhanmu Dialah yang lebih mengetahui tentang siapa yang tersesat dari jalan-Nya dan Dialah yang lebih mengetahui orang-orang yang mendapat petunjuk". (An-Nahl:125)

Istilah dakwah dalam agama Islam nampaknya tidak asing lagi, bahkan sudah dapat dikatakan popular sekali di kalangan masyarakat saat ini. Namun demikian yang sering kita jumpai sekarang bahwa istilah dakwah oleh kebanyakan orang diartikan hanya sebatas pengajian, ceramah, khutbah, atau mimbar seperti halnya yang sering dilakukan oleh ustadz, atau khatib. Dakwah sering di artikan sebagai sekedar ceramah dalam arti sempit. Kesalahan ini sebenarnya sering di ungkapkan, akp1an tetapi di dalam pelaksanaannya tetap saja terjadi penciutan agama. ${ }^{4}$

Untuk membuktikan keberhasilan dakwah,maka diperlukan konsep atau metode yang akan dipakai untuk berdakwah. Secara sosiologis hendaklah seorang da'i memahami bahwa konsep dakwah dapat dilihat dari tiga tingkatan: pertama, dakwah 
hanya bersifat tabligh, retorika, yakni hanya menyampaikan pesan kepada manusia. Kedua, dakwah yang berwujud usaha menanamkan nilai-nilai Islam ke tengah-tengah masyarakat. Dakwah pada tingkatan ini mengharuskan da'i mampu melakukan dialog antar budaya, mampu mendorong terjadinya sosialisasi, implimentasi dan akulturasi pewarisan budaya Islam dari satu generasi ke generasi berikutnya. Ketiga, dakwah membentuk masyarakat Islam, dari lingkungan pribadi, keluarga, hingga masyarakat negara, ataupun dunia. Pada tahap ini dakwah membutuhkan sistem jaringan dalam usaha membangun sistem Islam dalam semua segi kehidupan. ${ }^{5}$

Dengan berbagai peran dakwah yang dilakukan dalam mengatasi permasalahan dan berbagai problematika kehidupan yang ada saat ini, Lembaga eLPsikA yang merupakan lembaga terapan psikologi yang berada dibawah naungan Biro pendidikan dan pembudayaan juga memilikiperan yang sangat pentingdalampenyebarandakwah di masyarakatsekitarPondokPesantren AlAmienPrenduan.

Melihat berbagai problematika permasalahan yang dialami oleh masyarakat sekitar Pondok Pesantren khususnya masyarakat Pragaan laok, misalnya seperti pencurian, konflik keluarga, maupun masalah yang berkaitan dengan hal-hal yang bersifat mental, maka untuk mengurangi masalah-masalah tersebut, Lembaga EL-PsikA memulai dakwahnya dangan keterbukaan hati dan perhatian yang tulus.

Dalam pendekatan dakwah yang di terapkan lembaga EL-PsikA ini, serupa dengan dakwah yang pernah dialami oleh Rasulullah Saw. Saat Rasulullah Saw masih tinggal di kota Makkah, beliau pernah didatangi serombongan tamu yang terdiri dari pendeta-pendeta Nasrani Abessinia (Habasyah) yang berjumlah tujuh puluh orang. Ketika itu Rasulullah membacakan surah Yasin dengan memohon petunjuk dari Allah untuk memberikan hidayah kepada para tamu tersebut, akhirnya setelah beliau bacakan surat yasin tersebut para tamu Rasululah Saw langsung menyatakan beriman kepada

\footnotetext{
${ }^{5}$ Munir, Metode Dakwah. (Jakarta: Kencana. 2015). 319.
} 
Nabi Saw. 6

Dalam hal ini, mengingat pentingnya kehidupan yang Islami, tarbawi dan ma'hadi dikalangan masyarakat Pragaan laok, terutama dalam merubah kepribadian masyarakat Pragaan Laok, maka dalam hal ini lembaga EL-PsikA memiliki peran yang penting dalam merubah kepribadian masyarakat Pragaan Laok khususnya, bagi para masyarakat yang memiliki watak kepribadian yang keras melalui proses dakwah yang diberikan oleh lembaga tersebut.

Berdasarkan uraian diatas, peneliti menemukan keunikan yang menjadi titik permasalahan yang cukup menarik untuk diteliti. Salah satu keunikan itu adalah meskipun sebagian dari mereka tergolong masyarakat yang memiliki watak sangat keras ternyata mereka dapat merubah kepribadiannya melalui terapan dakwah dari eLPsikA. ${ }^{7}$ Berkaitan dengan hal tersebut, maka hati peneliti terpanggil untuk mengkaji dan menganalisis permasalahan dalam bentuk skripsi yang berjudul "Peran Dakwah Lembaga EL-PsikA Al-Amien Prenduan Terhadap Perubahan Kepribadian Masyarakat (Studi Kasus Masyarakat di Desa Pragaan Laok Kec. Pragaan Kab. Sumenep Tahun 2018 M.)"

\section{METODE PENELITIAN}

Dalam penelitian ini, metode yang dilakukan adalah metode penelitian kualitatif lapangan. Dengan jenis penelitian studi kasus. Studi kasus adalah studi yang mengeksplorasi suatu masalah dengan batasan terperinci, memiliki pengambilan data yang mendalam, dan menyertakan berbagai sumber informasi. Adapun alasan peneliti memilih jenis penelitian ini karena dalam penelitian ini data yang dihasilkan berupa data deskriptif yang diperoleh dari data-data berupa tulisan, kata-kata, dan dokumen.yang berasal dari sumber atau informan yang diteliti dan dapat dipercaya.

Untuk memperoleh data penelitan yang akurat dan dapat dipertanggungjawabkan, maka perlu menggunakan metode pengumpulan data yang

\footnotetext{
${ }^{6}$ Ali Mustofa Yakub. Sejarah \& Metode Dakwah Nabi. (Jakarta: Pustaka Firdaus, 2018) 208.

${ }^{7}$ Warta Singkat, eL-PsikA, t.t., t.p., 2014, 17.
} 
akurat pula, sesuai dengan data yang ingin dikumpulkan. Untuk keperluan tersebut, tehnik pengumpulan data yang digunakan dalam penelitian ini adalah wawancara, observasi, dokumentasi. Pengecekan keabsahan data menggunakan reduksi data, kategorisasi, sintesisasi, menyusun hipotesa kerja dan menganalisa dengan menggunakan triangulasi.

\section{HASIL PENELITIAN DAN PEMBAHASAN}

\section{Peran Dakwah Lembaga eL-PsikA Al-Amien Prenduan}

Peran dakwah merupakan aspek dinamis kedudukan (status), apabila seseorang melaksanakan hak dan kewajibannya sesuai dengan kedudukannya, istilah peran dalam "kamus bahasa Indonesia" mempunyai arti sandiwara. Peran ideal pada hakikatnya, dapat di terjemahkan sebagai peran yang diharapkan dan dilakukan oleh pemegang peranan tersebut.Dalam hal ini, peneliti menggunakan beberapa prinsip yaitu pendekatan penawaran, pendekatan Dengan cara hikmah, pendekatan bil mau'idah hasanah.

\section{a. Pendekatan Penawaran}

Salah satu falsafah pendekatan penawaran yang dilakukan Nabi adalah ajakan untuk beriman kepada Allah tanpa menyekutukan-Nya dengan yang lain. Cara ini dilakukan Nabi dengan memakai metode yang tepat tanpa paksaan sehingga mad'u meresponnya tidak dalam keadaan tertekan, bahkan ia melakukanya dengan niat yang timbul dari hati yang paling dalam.

Dalam hal ini, metode penawaran Islam kepada kabila-kabilah di tempat itu Nabi SAW mendatangi kabilah-kabilah untuk menawarkan Islamseraya mencari dukungan keamanan dari mereka. Dukungan dari kabilah-kabilah itu diperlukan mengingat semenjak Nabi SAW berdakwah secara terbuka, orangorang musyrikin dari kaum Quraisy selalu meneror beliau sehingga keamanan jiwa beliau terancam. ${ }^{8}$

\section{b. Pendekatan Dengan Cara Hikmah}

${ }^{8}$ Munir, Metode Dakwah, (Jakarta: Kencana. 2015), 23. 
Metode dakwah dengan cara hikmah. Yaitu dakwah al-Hikmah yang berarti dakwah bijak, mempunyai makna selalu memperhatikan suasana, situasi, dan kondisi mad'u dan al-Hikmah ditunjukkan kepada mad'u yang kapasitas intelektual terorganisasikan, cendikiawan, atau ilmuan. Dakwah dengan cara alHikmah yang terpenting adalah bahwa ajakan atau penyampaian ajaran agama dapat mendorong dan merangsang orang untuk menjalankan nilai-nilai atau ajaran agama. Dakwah yang dilakukan untuk mendorong orang meperbaiki diri, dari yang kurang baik menjadi baik, dari yang baik menjadi lebih baik, dan seterusnya. ${ }^{9}$

Menurut al-Qahtany, hikmah dalam konteks metode dakwah tidak dibatasi hanya dalam bentuk dakwah dengan ucapan yang lembut, targhib (nasehat mutivasi), kelembutan seperti selama ini dipahami orang. Lebih dari itu hikmah sebagai metode dakwah juga meliputi seluruh pendekatan dakwah dengan kedalaman rasio, pendidikan, nasehat yang baik, dialok yang baik pada tempatnya, juga dialok dengan para penentang yang zalim pada tempatnya, hingga meliputi kecaman dan ancaman. Dari sini diperoleh pemahaman bahwa pendekatan hikmah adalah induk dari semua metode dakwah yang intinya menekankan atas ketepatan pendekatan terkait dengan kelompok mad'u yang di hadapi

\section{c. Pendekatan Bil Mau'idah Hasanah}

Dakwah dengan metode mau-idhah hasanah yaitu sering diartikan dengan pelajaran yang baik dan dipraktekkan dalam bentuk cara ceramah keagamaan. Nasehat tentang kebaikan adalah kunci dalam metode ini. Salah satu bentuk pemberian nasehat adalah dengan cara memberikan ceramah keagamaan. Sebagai salah satu pengembangan konsep ini adalah pemberian materi atau pelajaran yang baik, dalam arti materi mendorong orang untuk melakukan kebaikan. Di antara pelaksanaan konsep dakwah ini adalah

\footnotetext{
${ }^{9}$ Ropingi Ishaq, Pengantar IImu Dakwah (Malang: Madani, 2016), 112.
} 
pelaksanaan pendidikan, baik secara klasikal maupun dalam bentuk sorongan. ${ }^{10}$

Adapun pendekatan dakwah mau'idah hasanah melalui pembinaan yaitu dilakukan dengan penanaman moral dan etika (budi pekerti) seperti kesabaran, keberanian, menepati janji, welas asih, hingga kehormatan diri serta menjelaskan efek dan manfaatnya dalam kehidupan bermasyarakat, disamping menjauhkan mereka dari perangai-perangai tercela yang dapat menghancurkan kehidupan seperti emosional, khianat, pengecut dan bakhil. ${ }^{11}$

\section{Kesimpulan}

Berdasarkan hasil penelitian pada bab IV maka peneliti dapat mengambil beberapa kesimpulan dari peran dakwah lembaga eL-PsikA dalam merubah kepribadian masyarakat dengan beberapa metode pendekatan sebagai berukut:Peran dakwah lembaga eL-PsikA Al-Amien Prenduan memiliki beberapa metode dalam pendekatannya kepada masyarakat yaitu pertama, pendekatan penawaran yang di terapkan oleh lembaga eL-PsikA sangat erat hubungannya dengan kehidupan sehari-hari dengan adanya beberapa tausiyah Seperti tingkah laku atau akhlaq, pendidikan, kehidupan berumah tangga, ekonomi dan lain sebagainya. Yang meliputi batiniyah, sehingga sangat dekat dengan pendekatan psikologi yang berkaitan dengan kejiwaan seseorang.Kedua, pendekatan dengan cara hikamh Yaitu dakwah al-Hikmah yang berarti dakwah bijak, mempunyai makna selalu memperhatikan suasana, situasi, dan kondisi mad'u dan al-Hikmah ditunjukkan kepada mad'u yang kapasitas intelektual terorganisasikan, cendikiawan, atau ilmuan.Maka proses pendekatan dakwah yang berhubungan langsung dengan masyrakat sekitar dan sasaran dakwah lembaga eLPsikA. Dimana hal tersebut sangat berpengaruh bagi masyarakat terhadap strategi penyampaian dakwahnya. Maka seorang da'i juga harus mampu bersosialisasi dengan apa yang terjadi dikalangan masyarakat.Ketiga, pendekatan ini sering diartikan dengan pelajaran yang baik dan diprektekan dalam bentuk cara ceramah keagamaan. Nasehat

10 Ropingi Ishaq, Pengantar IImu Dakwah (Malang: Madani, 2016), 119.

11 Ilyas Ismail, Filsafat Dakwah Rekayasa Membangun Agama Dan Perubahan Islam, (Jakarta: Kencana, 2011), 205. 
tentang kebaikan adalah kunci dalam metode ini. Salah satu bentuk pemberian nasehat adalah dengan cara memberikan perhatian secara khusus kepada masyarakat.

\section{Referensi atau Daftar Pustaka (bukan bibliografi)}

Alwisol. 2014. Psikologi Kepribadian Malang: UMM press.

Ali Mustofa Yakub. 2018. Sejarah \& Metode Dakwah Nabi. Jakarta: Pustaka Firdaus.

Didin Hafidhuddin, 2000, Dakwah Aktual, Jakarta Gema Insani Press.

Departemen Agama, 1971, Al-Qur'an Dan Terjemahan. Jakarta.

El Ishaq, Ropingi. 2016. Pengantar Ilmu Dakwah. Malang: Madani.

Fathi Yakan, 2012. Memotret Wajah Dakwah, Surakarta: Era Adi Citra.

Hamidi, 2010. Teori Komunikasi dan strategi Dakwah, Malang: UMM Pres.

Ilyas Ismail, 2012. Filsafat Dakwah Rekayasa Membangun Agama Dan Peradapan Islam, Jakarta: Kencana.

Jalaluddin. 2012. Psokologi Agama. Jakarta: PT RajaGrafindo Persada.

Moleong, Lexy J. 2011. Metode Penelitian Kualitatif. Bandung: Remaja Rosdakarya.

M. Munir , Wahyu llahi, 2012 Manajemen Dakwah, Jakarta: Kharisma Putra Utama.

Koentjaraningrat. 2009. Pengantar IImu Antropologi. PT Renica Cipta Jakarta.

Rusli, Mohammad. 2013.Metode Penelitian Kuantitatif dan Kualitatif Berorientasi Praktis. Sumenep: LP3 Paramadani.

Raco, J.R. t.th. Metode Penelitian Kualitatif. Jakarta: Grasindo.

Sugiyono. 2015. Metode Penelitian Dengan Pendekatan Kuantitatif, Kualitatif, Dan R\&D. Bandung: Alfabet.

Soerjono Soekanto, 2014,Sosiologi Suatu Pengantar (Kota Depok:Rajakrafindo Persada.

Tim Penyusun. 2016. Pedoman Penulisan Karya IImiah. t.t. Institut Dirosat Islamiyah Al-Amien Prenduan.

Wahyu llahi, 2013 Komunikasi Dakwah, Bandung: PT Remaja Rasda Karya. Warta Singkat, eL-PsikA, t.t., t.p., 2014, 17. 
Suhendi | Hudan Lin Naas, Volume 2, No. 2, Juli - Desember 2021 